\title{
Assessing the Specific Energy Consumption and Physical Properties of Comminuted
}

\section{Douglas-fir Chips for Bioconversion}

\author{
YalanLiu $^{\mathrm{a}^{*}}$ JinwuWang $^{\mathrm{a}}$ Michael Wolcott $^{\mathrm{a}}$ \\ ${ }^{a}$ Composite Materials \& Engineering Center, Washington State University, Pullman WA
} 99164-1806

*Correspondence to: Yalan Liu (Email: yalan.liu@wsu.edu)

\begin{abstract}
:
Size reduction homogenizes the bulk biomass and facilitates downstream feedstock handling, transportation, and storage. Effects of feeding rate, mill-type (hammer and knife mill), screen size, and moisture content on comminution energy consumption of commercial Douglas-fir (Pseudotsuga menziesii) pulp chips were quantified. The resulting particles were characterized by geometric mean diameter, size distribution, aspect ratio and bulk density. We also employed scanning electron microscopy (SEM) to visualize the dominant fracture surface features. A linear regression was used to describe the relationship between specific energy consumption (SEC) and comminution ratio, which can be used for estimating SEC of various particle sizes of feedstock. Results demonstrated that with a screen size $3.18 \mathrm{~mm}$, the hammer mill consumed $141 \mathrm{~kJ} \mathrm{~kg}^{-1}$, while the knife mill consumed $345 \mathrm{~kJ} \mathrm{~kg}^{-1}$. Selecting the feeding rate, which allows the machine reach its rated power, can result in lowest total SEC. SEC also increased substantially with an increase in moisture content from $11 \%$ to $17 \%$ (fraction in total mass basis). Analysis of the particle morphology revealed that the dominant fracture mechanism was across lumen for hammer milling and along middle lamella for knife milling.
\end{abstract}




\section{Keywords:}

Size reduction, comminution ratio, feeding rate, geometric mean diameter, fracture mechanism

\section{Introduction}

Commercial operations for producing second-generation biofuels and bioproducts are currently focused on using lignocellulosic biomass for both biochemical and thermochemical conversion (Anex et al., 2010; Brown et al., 2013; Weimer, 2008). All processes, regardless of feedstock type, require comminution to convert the raw biomass into a feedstock suitable for industrial us (Bitra et al., 2009; Dukes et al., 2013; Tumuluru et al., 2014). To maximize usable net energy or energy return on investment of the resulting fuel (Gingerich and Hendrickson, 1993), a primary goal of any comminution system must be to minimize the energy that is expended in the process. In addition, processing systems should be designed to engineer biomass into feedstock particles to benefit downstream industrial processes for materials handling and treatment efficacy.

Particle Morphology and Performance: The particle size of the feedstock is one key parameter for successful gasification (McKendry, 2002). Utilizing small particle sizes increases gas yield and energy efficiency due to the large surface area and fast rate of heat transfer (Kumar et al., 2009). In biochemical processing, reducing the size of the feedstock improves overall conversion rate up to $50 \%$ by influencing biomass digestibility (Vidal et al., 2011), while total conversion of enzymatic hydrolysis increases as particle size decreases (Khullar et al., 2013). 
Bulk density is an important factor for influencing transportation and storage costs and is highly dependent on particle size, size distribution, aspect ratio, and moisture content (MC). Size reduction can increase the bulk density and particle surface area of the feedstock (Chevanan et al., 2010; Ghorbani et al., 2012; Miao et al., 2011). Kronbergs et al.(2012) found a nonlinear relationship between feedstock bulk density and screen size for hammer milling. Bulk density of the resulting feedstock was found to decrease as the opening diameter of the screen increased. Similarly, other researchers reported a power-law relationship between bulk density and the geometric mean diameter of the particle (Adapa et al., 2011; Lam et al., 2008). Bulk density has been found to increase with decreasing aspect ratio of wood particles (Gozdecki et al., 2011). But a high particle aspect ratio is favorable for particle ignition because oxygen can be easily transferred to the ignition point (Gera et al., 2002).

Particle morphology influences the conversion process through the resulting surface chemistry and surface area. By using different refining techniques, the exposed fracture surface has been found to possess various compositions of lignin, cellulose and hemicellulose (Zhu, 2011).

Assessing Energy Consumption in Processing: Although size reduction improves feedstock uniformity and downstream conversion efficacy, it is an energy-intensive process. The energy consumption is commonly expressed as specific energy consumption (SEC), i.e. electrical or mechanical energy consumed per unit of mass. The total SEC can be computed by integrating the area under the power consumption curve with respective to time. This data is typically collected using a wattmeter and normalized to the total consumed energy using the mass of 
processed material. In turn, the net SEC is obtained by subtracting the idle energy consumption from total SEC (Mani et al., 2004; Repellin et al., 2010).

The measured SEC depends on many variables, including material characteristics (species, moisture content, feedstock original size, etc.), grinding mechanism, equipment design, and operational parameters (feeding rate). Specifically, the feedstock composition and grinding mechanism influence the SEC through both physical properties and fracture modes. For instance, the grinding energy of beech (Fagus spp.) was found to be $3060 \mathrm{~kJ} \mathrm{~kg}^{-1}$, which is higher than spruce (Picea spp.) of $2700 \mathrm{~kJ} \mathrm{~kg}^{-1}$ at a given screen size $0.5 \mathrm{~mm}$ (Repellin et al., 2010). Energy consumption has been found to be strongly affected by MC, because the moisture of the cell wall significantly influences the toughness property and shear strength of the biomass (Annoussamy et al., 2000; Glass and Zelinka, 2010). When moisture content increases from $7-9 \%$ to $11-13 \%$ (fraction in total mass basis), the SEC of both hammer mill and knife mill increased (Mani et al., 2004; Miao et al., 2011).

Processing method also has a strong influence on SEC. Schell and Hardwood (1994) reported that a disk mill consumed five times more energy than a hammer mill and produced particles with a larger size distribution. In addition, the energy consumption of a knife mill was found to be 2-3 times higher than that of a hammer mill with the same screen size ( $1 \mathrm{~mm}$ and $2 \mathrm{~mm})$ and the same feedstock when milling grasses (miscanthus and switchgrass). Knife-milled grindings also resulted in higher bulk density at the same screen size (Miao et al., 2011). In addition, screen size used to classify material on these milling machines influence the resulting particle sizes and therefore, the required energy consumption. The electric energy required to produce poplar and aspen particles of $0.85 \mathrm{~mm}$ in length is over five times higher 
than that for producing $2 \mathrm{~mm}$ long particles (Holtzapple et al., 1989). Many studies showed that high energy was required for fine grinding of both hard wood chips and agricultural biomass materials (Datta, 1981; Fang et al., 1997; Himmel et al., 1985; Mani et al., 2004; Martin and Behnke, 1984). Other studies demonstrated that the energy consumption of knife milling decreased as screen size increases (Mani et al., 2004; Zhang et al., 2012). In addition, SEC of a forage chopper and a hammer mill could be represented using a power-law relationship with screen size (Adapa et al., 2011). Energy consumption also varies with operational parameters e.g. rotating speed and feeding rate, due to its influence on equipment efficiency. Total SEC has been found to decrease with a second-order polynomial function as feeding rate increases (Bitra et al., 2009).

While delineating energy requirements and product attributes for comminution processes for biomass, the specific objectives of this study are to investigate the:

1. Effects of feeding rate, mill type, screen size and moisture content on SEC of the comminution process for softwood chips, specifically Douglas-fir (Pseudotsuga menziesii).

2. The relation between SEC and physical properties (geometric mean diameter, aspect ratio and bulk density) and fracture surface morphology of the resulted grindings.

\section{Material and Methods}

\subsection{Wood chip preparation}

Douglas-fir (Pseudotsuga menziesii) pulp chips were acquired from Vaagen Brothers Lumber Inc. located at Colville, Washington, in November 2012. The trees were about 80 years old and harvested from west of the Cascade Crest to the Pacific Ocean area. The lumber was 
chipped into pulp chips at a green state. The initial moisture content of chips was $51 \%$ (fraction in total mass basis). The received chips were screened into three portions over a gyratory screen (Model 580, Serial 4095-76, Black Clawson, Everett, WA), with the accepted chips passing a $25.4 \mathrm{~mm}$ top deck and retained on a $4.75 \mathrm{~mm}$ bottom deck. The accepted chips were air dried at ambient temperature to a moisture content of approximately $13 \%$ and subsequently stored in environmental moisture conditioner room (at a moisture level of $11 \%$ ) before use.

\subsection{Specific energy consumption of comminution}

Chips were ground with a hammer mill (Prater, $14.9 \mathrm{~kW}$ ) using one of five screen sizes $(11.11,6.35,3.18,1.59$ and $0.79 \mathrm{~mm})$ and a knife mill (Nelmor, $3.7 \mathrm{~kW})$ with one of four screen sizes $(9.53,6.35,4.76$ and $3.18 \mathrm{~mm})$. A $5 \mathrm{~kg}$ sample of Douglas-fir chips were manually fed into the hammer mill at a predetermined feed rate, and each test was performed in triplicate. In comparison to the hammer mill, the knife mill required a lower feed rate to achieve the rated power consumption. Therefore, a $2 \mathrm{~kg}$ material sample require ca. one hour to complete the milling process at a screen size of $3.18 \mathrm{~mm}$. The test order was randomized to eliminate the confounding effects of screen size and potential knife wear.

A Fluke 1735 Power Logger (Fluke Corporation, Everett, WA) was used to measure the electrical energy consumption of the hammer mill and knife mill and recorded as the realized power (i.e., the active power used by the motor) during the grinding process. An additional minute of data was collected before and after the grinding process to establish a machine baseline consumption for net power calculations. The total SEC was obtained by integrating the area under the power demand curve for the grinding time and dividing by the total oven- 
dried mass of wood that was ground in the session. Net SEC consumption was calculated by the following equation (Mani et al., 2004; Repellin et al., 2010).

$$
\text { Net SEC }=\frac{\text { Total enery }- \text { Idle energy }}{(\text { sample mass }) /(1+M C)}
$$

\subsection{Chip and particle characterization}

\subsubsection{Particle size and distribution}

After milling, the resulting particles were sieved with a Ro-Tap Shaker (The W. S. Tyler Company, Cleveland, Ohio) for 10 minutes to analyze the size distribution and geometric mean diameter following ASAE Standard S319.4 (2008). The geometric mean diameter $\left(\mathrm{X}_{\mathrm{gw}}\right)$ and standard deviation $\left(\mathrm{S}_{\mathrm{gw}}\right)$ were then calculated.

\subsubsection{Moisture content measurement}

The moisture content of the Douglas-fir wood chips and resulted grindings was determined according to ASAE Standard S358.2 (2006) for five replicate samples and expressed as a fraction in total mass. Three initial moisture content values were selected for the energy consumption comparison: $13 \%, 17 \%$, and $23 \%$. To achieve these levels, the air-dried chips were rehydrated to $17 \%$ and $23 \%$ levels by evenly spraying water on the chips and subsequently storage in plastic bags for one week to allow equilibration. Before grinding, the moisture content of wood chips was confirmed to be $16.5 \%$ and $23.2 \%$. A $6.35 \mathrm{~mm}$ screen was used to examine the influence of moisture content on the SEC of hammer and knife milling.

\subsubsection{Aspect ratio}

The aspect ratio of the ground wood particles was measured through image analysis of optical micrographs. Wood particles were placed on a black background platform and digital images 
were acquired through a stereomicroscope (Wild M-4A with Fluorescent Ring Light). Images of particles form each sieve were assessed with a digital image analysis software (Rasband, W.S., Image J, U. S. National Institutes of Health, Bethesda, Maryland, USA, 1997-2014.) and expressed as the weighted average aspect ratio according to size distribution results.

\subsubsection{Bulk density}

Bulk density of hammer-and knife-milled grindings was determined in accordance with ASTM E873-82 (2006) using a $7079 \mathrm{~cm}^{3}$ wooden cubic container. The difference between the filled and empty mass of the container was used to compute the bulk density using the following equation:

$$
\text { Bulk density }(\mathrm{BD})=\frac{(\text { Mass of container and sample })-(\text { Mass of container })}{(\text { Volume of container })(1+M C)}
$$

Bulk density was corrected to the oven dry mass. This measurement has been repeated five times to obtain the reported mean value and standard deviation.

\subsubsection{Morphology}

Images of fracture surface were obtained through SEM (FEI Quanta 200F, field emission gun, high vacuum, ETD detectors, FEI Company, Hillsboro, Oregon, USA) after sputter coating with gold.

\section{Results and discussion}

\subsection{Geometric mean diameter and size distribution}

Table 1 here.

Table 1 presents the moisture content, geometric mean diameter and bulk density of the resulting grindings. The geometric mean diameter of wood chips prior to grinding were 10.36 $\mathrm{mm}$. For a given screen size, the hammer mill produced finer grindings than knife mill. This 
finding is supported by comparing the cumulative frequency distributions of the particles produced with each process for a $6.35 \mathrm{~mm}$ and $3.18 \mathrm{~mm}$ screen (Figure1(a)).

Figure 1 here.

\subsection{Bulk density}

The grinding process increased the bulk density of the resulting particles, with the the particle bulk density increasing with decreasing screen size. The inverse relationship of bulk density and geometric mean diameter of the particles fits a power-law function for both hammer mill and knife mill particles (Figure 1(b)). Similarly, a power-law relationship was reported by Lam (2008) for scissor cutting particles of wheat straw and switchgrass biomass. Since the hammer mill produced finer particles than the knife mill at a given screen size, these smaller particle sizes should display a higher bulk density at similar conditions (Chevanan et al., 2010; Ghorbani et al., 2012; Miao et al., 2011). However, the knife-milled grindings resulted in consistently higher bulk densities than those from the hammer mill at the same screen size. This discrepancy was also noted by Miao (2011) for hammer and knife milled energy crop (miscanthus and switchgrass) particles.

\subsection{Aspect ratio}

In addition to geometric mean diameter, particle shape also contributes to differences in bulk density. The aspect ratio was determined for the $6.35 \mathrm{~mm}$ screen grindings for both hammer and knife milled material was completed following the sieve analysis. The weighted average was used to distinguish the difference between two mill types at the same screen size:

$$
\text { Wighted average Aspect ratio }=\frac{\sum_{i=1}^{n} \text { Aspect ratio }_{\mathrm{i}} * \operatorname{Mass}_{\mathrm{i}}}{\sum_{i=1}^{n} \operatorname{Mass}_{i}}
$$

The grindings from hammer mill possessed a higher average aspect ratio of 5.56 than 4.55 of 
the knife mill, which likely contributed to the decreased bulk density observed in this study and that of (Gozdecki et al., 2011). Others have found that larger aspect ratio particles bridge, resulting in increased voids and decreased bulk density during packing (Mahdavi et al., 2010). The hammer mill uses impact and shearing actions during milling, while the knife mill mainly produces cutting and impact forces. The cutting action tended to shorten fiber length, resulting in a smaller aspect ratio.

\subsection{Specific energy consumption}

Many variables (feeding rate, screen size, milling type, and moisture content of feedstock,) have been found to affect SEC (Miao et al., 2011; Womac et al., 2007). Feeding rate influences SEC through affecting motor efficiency. Decreasing of screen size increased SEC dramatically and different grinding mechanisms may resulted in various difference in SEC. Additionally, increasing of moisture content may increase SEC due to moisture bonding in wood cell wall structure.

\subsubsection{Feeding rate effect}

The feeding rate influenced specific energy consumption due to varying motor efficiencies with different loadings. Four feeding rates were selected for each screen according to preliminary test results. Table 2 demonstrates the SEC of the hammer and knife mills fitting with a $6.35 \mathrm{~mm}$ screens. The net SEC increased as feeding rate increased, while the total specific energy achieves a minimum at a feeding rate that had the motor approximately reached its rated full-load capacity. This trend was prominent for the hammer mill than the knife mill. In addition, total SEC began to decrease when operated maximum power of knife mill reached around $70 \%$ of its rated power, and then increased along with an increase of 
operated power.

Table 2 here.

\subsubsection{Screen size and milling type effect}

Figure 2 here.

A power law fitting between SEC and the geometric mean diameter is showed in Figure 2.

The power-law function between SEC and the geometric mean diameter of resulting particles suggests that the target particle size must be carefully determined to achieve a compromise between energy cost and size reduction. In addition, a hammer mill consumes less specific energy to comminute wood particles than the knife mill to result in a given size. For example, the hammer mill consumes $194 \mathrm{~kJ} \mathrm{~kg}^{-1}$ compared to $303 \mathrm{~kJ} \mathrm{~kg}^{-1}$ of knife mill to produce particles with a geometric mean diameter of $1.49 \mathrm{~mm}$ and $2.66 \mathrm{~mm}$, respectively. This observation for the softwood materials examined here, is consistent with Miao's (2011) findings for energy crops. Furthermore, the percent of idle specific energy in total energy of the knife mill is higher than that of hammer mill. Therefore, it is safe to conclude that the hammer mill is more energy-efficient than the knife mill.

\subsubsection{Knife dulling effect}

The cumulative consumed time of knife for each set of experiments had been recorded. It had been employed as a variate to evaluate its influence on SEC. Multivariate analysis of variance showed that time of knife uses in these experiments did not significantly affect SEC $(\alpha=0.05)$. The variability of SEC with knife use at the same screen size was further examined to be less than $5 \%$. The knife blades had been used for about 16 hours in total for this set of experiments. Therefore, the blade condition have not changed significantly. 


\subsubsection{Moisture content effect}

For to hammer mill, the net and total SEC increased by $83 \%$ and $66 \%$, respectively, when the moisture content increased from $13 \%$ to $16.5 \%$. But when further increasing the moisture content from $16.5 \%$ to $23.2 \%$, both SEC values increased by only an additional $23 \%$ (Figure 3). For the knife mill, the net and total SEC increased by $48 \%$ and $68 \%$, respectively as moisture content increased from $11.5 \%$ to $16.5 \%$, and when moisture content was further increased from $17 \%$ to $23 \%$, the increases of net and total SEC were only an additional $34 \%$ and $19 \%$. Below the fiber saturation point (22 to $23 \%$ for most wood species), free water, i.e. liquid water filling the cell lumens, is eliminated and only bound water adsorbed on the cell wall polymers exists. Consequently, it is the bound water that might contribute to the large energy increases found between $13 \%$ to $17 \%$, whereas free water contributes less energy consumption. This finding is consistent with the dependence of mechanical properties of wood on moisture content (Glass and Zelinka, 2010).

Figure 3 here.

\subsection{Morphology of grindings}

Figure 4 presents SEM images of grindings from hammer and knife mills. The fracture surfaces shown in Figure 4 (a) \& (c) represent earlywood, as evidenced by the obvious presence of the spiral thickenings. In contrast, those cells shown in Figure 4 (b) \& (d) were more likely latewood. The earlywood section of resulted grindings both have fracture modes across the lumen as shown in Figure 4 (a) \& (c). However, in the latewood region, the fracture mode along the middle lamella became dominant in knife-milled grindings, while fracture through lumen is dominant in both the earlywood and latewood of the hammer- 
milled grindings.

Figure 4 here.

\subsection{Discussion}

The physical characteristics of grindings were correlated with SEC based upon specific operating conditions. In order to comprehensively understand the relationship, we compared our results with those of other published studies investigating size reduction of woody material (Figure5). Whereas all of the data generally fits a power law relationship between SEC and geometric mean diameters, the variability of SEC between the published results appear high. These differences are due to different raw material conditions such as moisture content and initial feedstock size.

Figure 5 here.

To normalize the effect of initial size on SEC, comminution ratio (CR), first introduced by Cadoche (1989), was defined as the ratio between the initial and final particle size. Here, we computed $\mathrm{CR}$ as the ratio of initial and final geometric mean diameter of wood particles. A good linear regression between SEC and CR-1 was built (Figure 5 (b)), implying the importance of initial particle size on SEC.

Table 3 here.

Table 3 summarizes the properties of raw material, net SEC and mill type in the literatures. Esteban's initial chip size and moisture content of feedstock are quite similar to our initial chip size of $10.36 \mathrm{~mm}$ and moisture content of 11 13\% (Esteban and Carrasco, 2006). Their findings on SEC are also close to ours. Repellin's data suggests that the ZM1 ultra centrifugal mill consumes more energy than the hammer mill. However, the feedstock used in their study 
was green chips, which had a high moisture content. Also, the disk mill tends to consume more energy than the hammer mill and knife mill (Schell and Harwood, 1994; Zhu et al., 2010). When comparing data in literatures, these summarized properties may better explain the differences in SEC.

\section{Conclusions}

A linear regression can be used to describe the relationship between SEC and comminution ratio, which can be widely used for estimating SEC of various particle size of feedstocks. Importantly, the minimum total SEC was achieved at a feeding rates that produced the approximate rated power of the motor. Also, hammer milling produced finer wood particles with a higher aspect ratio and lower bulk density but consumed less energy than knife milling. The process SEC increased dramatically with an increase of moisture content from $11 \%-17 \%$. Fractures across the cell lumen dominated hammer-milled grindings, while fractures along middle lamellae dominated the knife-milled grindings.

\section{Acknowledgements}

The authors gratefully acknowledge the Northwest Advanced Renewables Alliance (NARA), supported by the Agriculture and Food Research Initiative Competitive Grant no. 201168005-30416 from the USDA National Institute of Food and Agriculture, and the China Scholarship Council funding for Yalan Liu's living expenses. 


\section{References}

Adapa, P., Tabil, L., Schoenau, G., 2011. Grinding performance and physical properties of non-treated and steam exploded barley, canola, oat and wheat straw. Biomass Bioenerg 35, $549-561$.

Anex, R.P., Aden, A., Kazi, F.K., Fortman, J., Swanson, R.M., Wright, M.M., Satrio, J.A., Brown, R.C., Daugaard, D.E., Platon, A., Kothandaraman, G., Hsu, D.D., Dutta, A., 2010. Techno-economic comparison of biomass-to-transportation fuels via pyrolysis, gasification, and biochemical pathways. Fuel 89, S29-S35.

Annoussamy, M., Richard, G., Recous, S., Guerif, J., 2000. Change in mechanical properties of wheat straw due to decomposition and moisture. Appl Eng Agric 16, 657-664.

ASAE Standard S358. 2 FEB03. Moisture Measurement-Forages, In: ASABE Standards. American Society of Agricultural and Biological Engineers, St. Joseph, Michigan, USA, 2006. p. 1-2.

ASAE Standard S319.4 FEB. Method of Determining and Expressing Fineness of Feed, In: ASABE Standards. American Society of Agricultural and Biological Engineers, St. Joseph, Michigan, USA, 2008. p. 663-665.

ASTM, 2006. E873-82 DEC. Standard Test Method for Bulk Density of Densified Particulate Biomass Fuels, In: ASTM Standards. ASTM, West Conshohocken, Pennsylvania, USA. Bitra, V.S., Womac, A.R., Igathinathane, C., Miu, P.I., Yang, Y.T., Smith, D.R., Chevanan, N., Sokhansanj, S., 2009. Direct measures of mechanical energy for knife mill size reduction of switchgrass, wheat straw, and corn stover. Bioresour. Technol. 100, 6578-6585.

Brown, T.R., Thilakaratne, R., Brown, R.C., Hu, G.P., 2013. Techno-economic analysis of 
biomass to transportation fuels and electricity via fast pyrolysis and hydroprocessing. Fuel 106, 463-469.

Cadoche, L., Lopez, G.D., 1989. Assessment of Size-Reduction as a Preliminary Step in the Production of Ethanol from Lignocellulosic Wastes. Biol Waste 30, 153-157.

Chevanan, N., Womac, A.R., Bitra, V.S.P., Igathinathane, C., Yang, Y.T., Miu, P.I., Sokhansanj, S., 2010. Bulk density and compaction behavior of knife mill chopped switchgrass, wheat straw, and corn stover. Bioresour. Technol. 101, 207-214.

Datta, R., 1981. Energy requirements for lignocellulose pretreatment processes. Process Biochem 16, 16-19,42.

Dukes, C.C., Baker, S.A., Greene, W.D., 2013. In-wood grinding and screening of forest residues for biomass feedstock applications. Biomass Bioenerg 54, 18-26.

Esteban, L.S., Carrasco, J.E., 2006. Evaluation of different strategies for pulverization of forest biomasses. Powder Technol 166, 139-151.

Fang, Q., Boloni, I., Haque, E., Spillman, C., 1997. Comparison of energy efficiency between a roller bill and a hammer mill. Appl Eng Agric 13, 631-635.

Gera, D., Mathur, M.P., Freeman, M.C., Robinson, A., 2002. Effect of large aspect ratio of biomass particles on carbon burnout in a utility boiler. Energ Fuel 16, 1523-1532.

Ghorbani, Z., Hemmat, A., Masoumi, A.A., 2012. Physical and Mechanical Properties of Alfalfa Grind as Affected by Particle Size and Moisture Content. J Agr Sci Tech-Iran 14, 6576.

Gingerich, J., Hendrickson, O., 1993. The Theory of Energy Return on Investment - a CaseStudy of Whole Tree Chipping for Biomass in Prince-Edward-Island. Forest Chron 69, 300- 
306.

Glass, S.V., Zelinka, S.L., 2010. Moisture Relations and Physical Properties of Wood, in:

Laboratory, F.P. (Ed.), Wood Handbook - Wood as an Engineering Material, General

Technical Report FPL-GTR-190. Department of Agriculture, Forest Service, Forest Products

Laboratory., Madison, WI: U.S., pp. 4:1-19.

Gozdecki, C., Zajchowski, S., Kociszewski, M., Wilczynski, A., Mirowski, J., 2011. Effect of wood particle size on mechanical properties of industrial wood particle-polyethylene composites. Polimery 56, 375-380.

Himmel, M., Tucker, M., Baker, J., Rivard, C., Oh, K., Grohmann, K., 1985. Comminution of biomass: hammer and knife mills. Biotechnol Bioeng Symp 15, 39-58.

Holtzapple, M., Humphrey, A., Taylor, J., 1989. Energy requirements for the size reduction of poplar and aspen wood. Biotechnol Bioeng 33, 207-210.

Khullar, E., Dien, B.S., Rausch, K.D., Tumbleson, M.E., Singh, V., 2013. Effect of particle size on enzymatic hydrolysis of pretreated Miscanthus. Ind. Crops Prod. 44, 11-17.

Kronbergs, A., Kronbergs, E., Rozinskis, R., 2012. Size Reduction of Common Reeds for Biofuel Production. Eng Rur Develop, 257-261.

Kumar, A., Jones, D.D., Hanna, M.A., 2009. Thermochemical Biomass Gasification: A Review of the Current Status of the Technology. Energies 2, 556-581.

Lam, P.S., Sokhansanj, S., Bi, X., Lim, C.J., Naimi, L.J., Hoque, M., Mani, S., Womac, A.R., Ye, X.P., Narayan, S., 2008. Bulk density of wet and dry wheat straw and switchgrass particles. Appl Eng Agric 24, 351-358.

Mahdavi, S., Kermanian, H., Varshoei, A., 2010. Comparison of Mechanical Properties of 
Date Palm Fiber-Polyethylene Composite. Bioresources 5, 2391-2403.

Mani, S., Tabil, L.G., Sokhansanj, S., 2004. Grinding performance and physical properties of wheat and barley straws, corn stover and switchgrass. Biomass Bioenerg 27, 339-352.

Martin, S., Behnke, K., 1984. Grinding efficiency and particle size effects on feed manufacturing operations. American Society of Agricultural Engineers Paper no. 84-3524, St. Joseph, MI.

McKendry, P., 2002. Energy production from biomass (part 3): gasification technologies. Bioresour. Technol. 83, 55-63.

Miao, Z., Grift, T.E., Hansen, A.C., Ting, K.C., 2011. Energy requirement for comminution of biomass in relation to particle physical properties. Ind. Crops Prod. 33, 504-513.

Repellin, V., Govin, A., Rolland, M., Guyonnet, R., 2010. Energy requirement for fine grinding of torrefied wood. Biomass Bioenerg 34, 923-930.

Schell, D.J., Harwood, C., 1994. Milling of lignocellulosic bimass: results of pilot-scale testing. Appl Biochem Biotech 45/46, 159-168.

Trass, O., Gravelsins, R., Stiasny, Z., 1987. Fine grinding of wood chips and wood wastes with the Szego mill, In: Sixth Canadian bioenergy R\&D seminar., Proceedings of the seminar held at Richmond, British Columbia, Canada.

Tumuluru, J.S., Tabil, L.G., Song, Y., Iroba, K.L., Meda, V., 2014. Grinding energy and physical properties of chopped and hammer-milled barley, wheat, oat, and canola straws. Biomass Bioenerg 60, 58-67.

Vidal, B.C., Jr., Dien, B.S., Ting, K.C., Singh, V., 2011. Influence of feedstock particle size on lignocellulose conversion--a review. Appl Biochem Biotechnol 164, 1405-1421. 
Weimer, A.W., 2008. Biochemical vs. Thermochemical Conversion of Biomass. Chem Eng Prog 104, 4-5.

Womac, A.R., Igathinathane, C., Bitra, P., Miu, P., Yang, T., Sokhansanj, S., Naraya, S., 2007. Biomass Pre-Processing Size Reduction with Instrumented Mills. ASABE Paper No.076046, ASABE, St. Joseph, MI.

Zhang, M., Song, X., Deines, T.W., Pei, Z.J., Wang, D., 2012. Biofuel Manufacturing from Woody Biomass: Effects of Sieve Size Used in Biomass Size Reduction. J. Biomed. Biotechnol. 2012: 581039

Zhu, J., 2011. Physical pretreatment—woody biomass sizereduction—for forest biorefinery, in: Zhu, J.Y., Zhang, X., Pan, X.J. (Eds.), Sustainable production of fuels, chemicals, and fibers from forest biomass. American Chemical Society, Washington, DC, pp. 89-107. Zhu, W., Zhu, J.Y., Gleisner, R., Pan, X.J., 2010. On energy consumption for size-reduction and yields from subsequent enzymatic saccharification of pretreated lodgepole pine. Bioresour. Technol. 101, 2782-2792. 


\section{Table Captions}

Table 1. Geometric mean diameter and bulk density of grindings of hammer mill and knife mill

Table 2. Specific Energy Consumption of hammer mill and knife mill fitting at $6.35 \mathrm{~mm}$ screen with an increase in feeding rate

Table 3. Specific Energy Consumption of comminuting lignocellulosic materials

\section{Figure Captions}

\section{Figure 1.}

(a) Cumulative distribution of hammer-milled $(\mathrm{H})$ and knife-milled $(\mathrm{K})$ grindings at 6.35 and

$3.18 \mathrm{~mm}$ screen; (b) Bulk density transformation of resulting particles along with geometric mean diameter

Figure 2. Specific Energy Consumption of hammer mill and knife mill with an increase in geometric mean diameter

Figure 3. Moisture content effects on Specific Energy Consumption of hammer mill and knife mill fitting with $6.35 \mathrm{~mm}$ screen

Figure 4.SEM images of (a), (b): hammer mill grinds; (c), (d): knife mill grinds

Figure 5. Relation between Net Specific Energy Consumption and (a) geometric mean diameter, (b) comminution ratio -1 for hammer $(\mathrm{H})$ and knife $(\mathrm{K})$ milling processes. 
Table 1

\begin{tabular}{llllllllll}
\hline Mill type & \multicolumn{3}{c}{ Hammer mill } & \multicolumn{7}{c}{ Knife mill } \\
Screen size (mm) & 11.11 & 6.35 & 3.18 & 1.59 & 0.79 & 9.53 & 6.35 & 4.76 & 3.18 \\
\hline Moisture content $(\%)$ & 12.7 & 12.2 & 12.4 & 11.3 & 8.1 & 12.3 & 11.6 & 10.9 & 9.0 \\
$\mathrm{X}_{\mathrm{gm}}{ }^{\mathrm{a}}(\mathrm{mm})$ & 2.25 & 1.49 & 1.02 & 0.84 & 0.65 & 4.66 & 2.66 & 1.94 & 1.54 \\
$\mathrm{~S}_{\mathrm{gm}}{ }^{\mathrm{b}}(\mathrm{mm})$ & 1.88 & 1.81 & 1.78 & 1.75 & 1.83 & 1.77 & 1.83 & 1.76 & 1.86 \\
Bulk density $\left(\mathrm{kg} \mathrm{m}^{-3}\right)$ & 189 & 204 & 218 & 240 & 267 & 214 & 246 & 263 & 283 \\
Optimal feeding rate $(\mathrm{kg}$ & 8.7 & 7.1 & 3.9 & 3.3 & 2.3 & 5.7 & 3.0 & 2.3 & 1.1 \\
min $\left.^{-1}\right)$ & & & & & & & & & \\
Total SEC $\left(\mathrm{kJ} \mathrm{kg}^{-1}\right)$ & 113 & 194 & 310 & 524 & 734 & 138 & 303 & 370 & 1050 \\
Net SEC $\left(\mathrm{kJ} \mathrm{kg}^{-1}\right)$ & 59 & 95 & 141 & 223 & 328 & 70 & 153 & 205 & 345 \\
\hline
\end{tabular}

a: Geometric mean diameter

b: Standard deviation 
Table 2

\begin{tabular}{|c|c|c|c|c|c|c|c|}
\hline \multicolumn{4}{|c|}{ Hammer mill } & \multicolumn{4}{|l|}{ Knife mill } \\
\hline $\begin{array}{l}\text { Feeding } \\
\text { rate } \\
\left(\mathrm{kg} \mathrm{min}^{-1}\right)\end{array}$ & $\begin{array}{l}\text { Maximum } \\
\text { power } \\
(\mathrm{kW})\end{array}$ & $\begin{array}{l}\text { Net } \\
\text { SEC } \\
\left(\mathrm{kJ} \mathrm{kg}^{-1}\right)\end{array}$ & $\begin{array}{l}\text { Total } \\
\text { SEC } \\
\left(\mathrm{kJ} \mathrm{kg}^{-1}\right)\end{array}$ & $\begin{array}{l}\text { Feeding } \\
\text { rate } \\
\left(\mathrm{kg} \mathrm{min}^{-1}\right)\end{array}$ & $\begin{array}{l}\text { Maximum } \\
\text { power } \\
(\mathrm{kW})\end{array}$ & $\begin{array}{l}\text { Net } \\
\text { SEC } \\
\left(\mathrm{kJ} \mathrm{kg}^{-1}\right)\end{array}$ & $\begin{array}{l}\text { Total } \\
\text { SEC } \\
\left(\mathrm{kJ} \mathrm{kg}^{-1}\right)\end{array}$ \\
\hline 4.7 & 10.5 & 87 & 219 & 1.3 & 1.6 & 156 & 313 \\
\hline 6.0 & 12.4 & 93 & 208 & 3.0 & 2.4 & 153 & 303 \\
\hline 7.1 & 14.5 & 95 & 195 & 6.9 & 3.3 & 162 & 311 \\
\hline 8.8 & 18.6 & 104 & 205 & 11.6 & 3.5 & 154 & 324 \\
\hline
\end{tabular}


Table 3

\begin{tabular}{|c|c|c|c|c|c|c|}
\hline $\begin{array}{l}\text { Feedstock } \\
\text { species }\end{array}$ & $\begin{array}{l}\text { Moisture } \\
\text { content } \\
(\%)\end{array}$ & $\begin{array}{l}\text { Initial } \\
\text { size(mm) }\end{array}$ & $\begin{array}{l}\text { Final size } \\
(\mathrm{mm})\end{array}$ & Mill type & $\begin{array}{l}\text { Net } \\
\operatorname{SEC}(\mathrm{kJ} \\
\left.\mathrm{kg}^{-1}\right)\end{array}$ & Resources \\
\hline Poplar & $9.9 \sim 14.9$ & 9.52 & 0.42 & $\begin{array}{l}\text { Hammer } \\
\text { mill } \\
(11 \mathrm{~kW})\end{array}$ & $297^{c}$ & $\begin{array}{l}\text { (Esteban } \\
\text { and } \\
\text { Carrasco, } \\
\text { 2006) }\end{array}$ \\
\hline Pine & $9.9 \sim 14.9$ & 12.1 & 0.41 & $\begin{array}{l}\text { Same as } \\
\text { above }\end{array}$ & $429^{c}$ & $\begin{array}{l}\text { (Esteban } \\
\text { and } \\
\text { Carrasco, } \\
\text { 2006) }\end{array}$ \\
\hline Hardwood & $3.8 \sim 6.5$ & $22.4 / 22.9$ & $1.6 / 2.54$ & $\begin{array}{l}\text { Hammer } \\
\text { mill }(11.2 \\
\mathrm{kW})\end{array}$ & $468 / 432$ & $\begin{array}{l}\text { (Cadoche } \\
\text { and Lopez, } \\
1989 \text { ) }\end{array}$ \\
\hline Hardwood & $3.8 \sim 6.5$ & $22.4 / 22.9$ & $1.6 / 2.54$ & $\begin{array}{l}\text { Knife mill } \\
(7.5 \mathrm{~kW})\end{array}$ & $468 / 264$ & $\begin{array}{l}\text { (Cadoche } \\
\text { and Lopez, } \\
1989 \text { ) }\end{array}$ \\
\hline $\begin{array}{l}\text { Lodgepole } \\
\text { pine }\end{array}$ & 0 & $\begin{array}{r}\mathrm{L}^{\mathrm{a}}: 6 \sim 38 \\
\mathrm{~T}^{\mathrm{a}}: 3 \sim 8\end{array}$ & $0.76^{\mathrm{b}}$ & Disk mill & 2217 & $\begin{array}{l}\text { (Zhu et al., } \\
2010 \text { ) }\end{array}$ \\
\hline $\begin{array}{l}\text { Poplar and } \\
\text { Aspen }\end{array}$ & 12 & $25.4 \times 6.4$ & 2 & $\begin{array}{l}\text { Two-stage } \\
\text { hammer } \\
\text { mill }\end{array}$ & 180 & $\begin{array}{l}\text { (Holtzappl } \\
\text { e et al., } \\
\text { 1989) }\end{array}$ \\
\hline Spruce & Green & $2 \sim 4$ & 0.237 & $\begin{array}{l}\text { ZM1 ultra } \\
\text { centrifugal } \\
\text { mill }\end{array}$ & $2700^{c}$ & $\begin{array}{l}\text { (Repellin } \\
\text { et al., } \\
2010 \text { ) }\end{array}$ \\
\hline Beech & Green & $2 \sim 4$ & 0.284 & $\begin{array}{l}\text { Same as } \\
\text { above }\end{array}$ & $3060^{c}$ & $\begin{array}{l}\text { (Repellin } \\
\text { et al., } \\
2010)\end{array}$ \\
\hline Aspen & 33.3 & $20 \times 20 \times 3$ & $0.93^{\mathrm{d}}$ & $\begin{array}{l}\text { Ring roller } \\
\text { mill (14.9 } \\
\mathrm{kW})\end{array}$ & 504 & $\begin{array}{l}\text { (Trass et } \\
\text { al., 1987) }\end{array}$ \\
\hline Poplar & 37.5 & NA & $1.5^{\mathrm{d}}$ & $\begin{array}{l}\text { Hammer } \\
\text { mill }\end{array}$ & 320 & $\begin{array}{l}\text { (Schell } \\
\text { and } \\
\text { Harwood, } \\
\text { 1994) }\end{array}$ \\
\hline Poplar & 37.5 & NA & $0.38^{\mathrm{b}}$ & Knife mill & 2484 & $\begin{array}{l}\text { (Schell } \\
\text { and } \\
\text { Harwood, } \\
\text { 1994) }\end{array}$ \\
\hline Willow & 13 & $\begin{array}{l}60-580 \times 60- \\
760 \times 50-250\end{array}$ & 2.12 & Knife mill & 203 & $\begin{array}{l}\text { (Miao et } \\
\text { al., 2011) }\end{array}$ \\
\hline
\end{tabular}

a. L: length, T: thickness 
b. This data is Screen size, final size of particle is not available

c. This data is total specific energy consumption

d. This data is d50 mass median diameter 


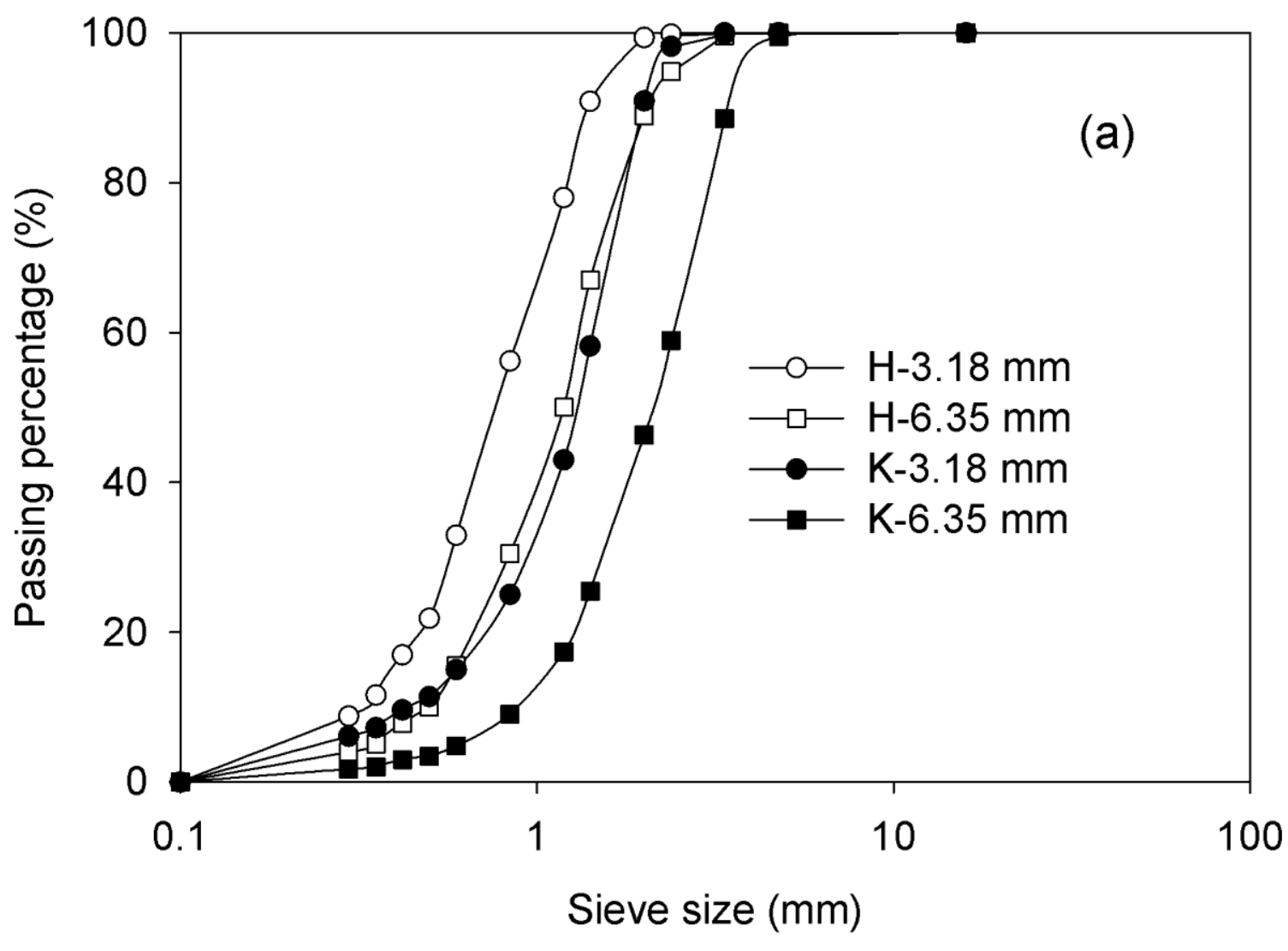




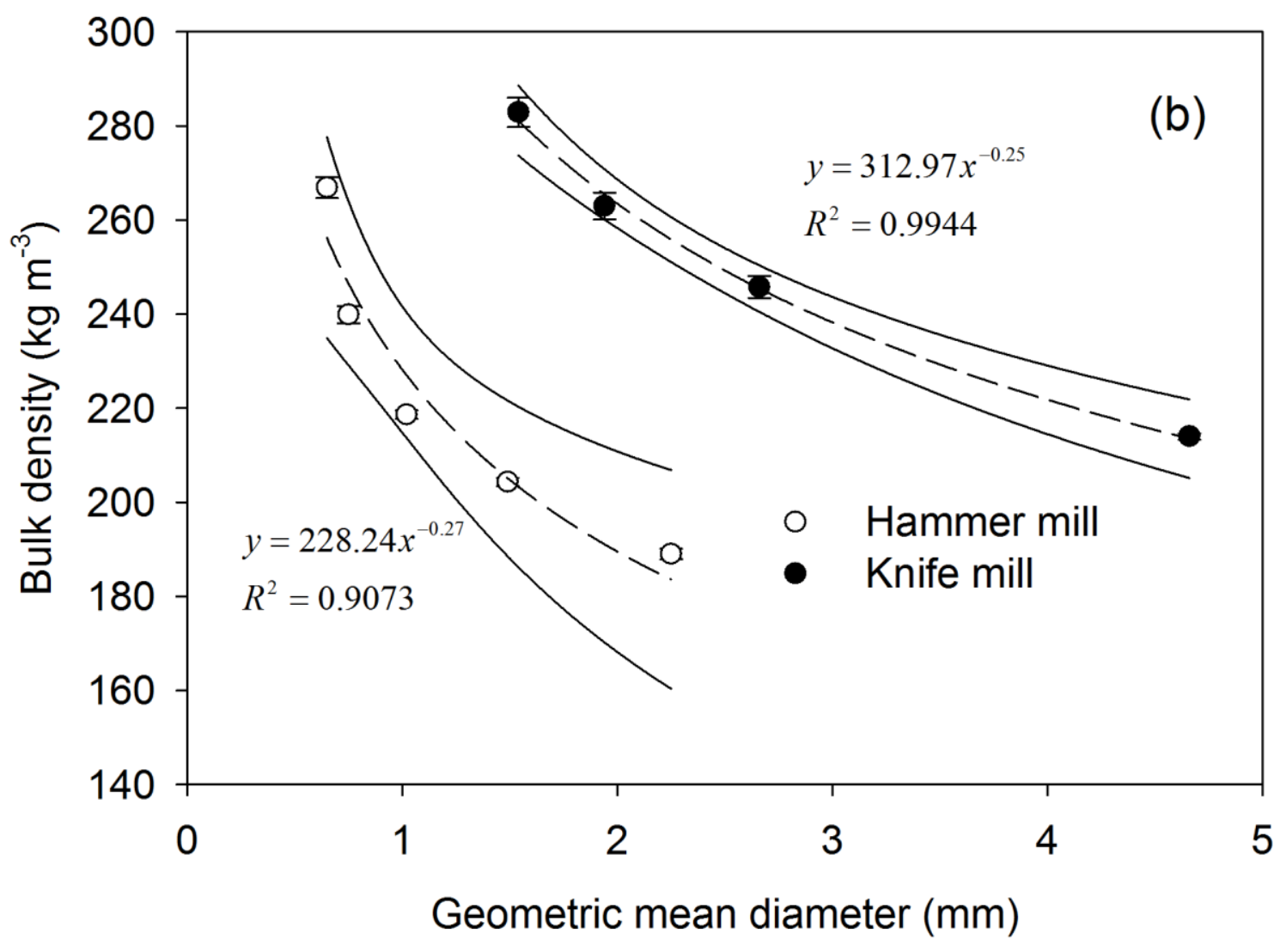




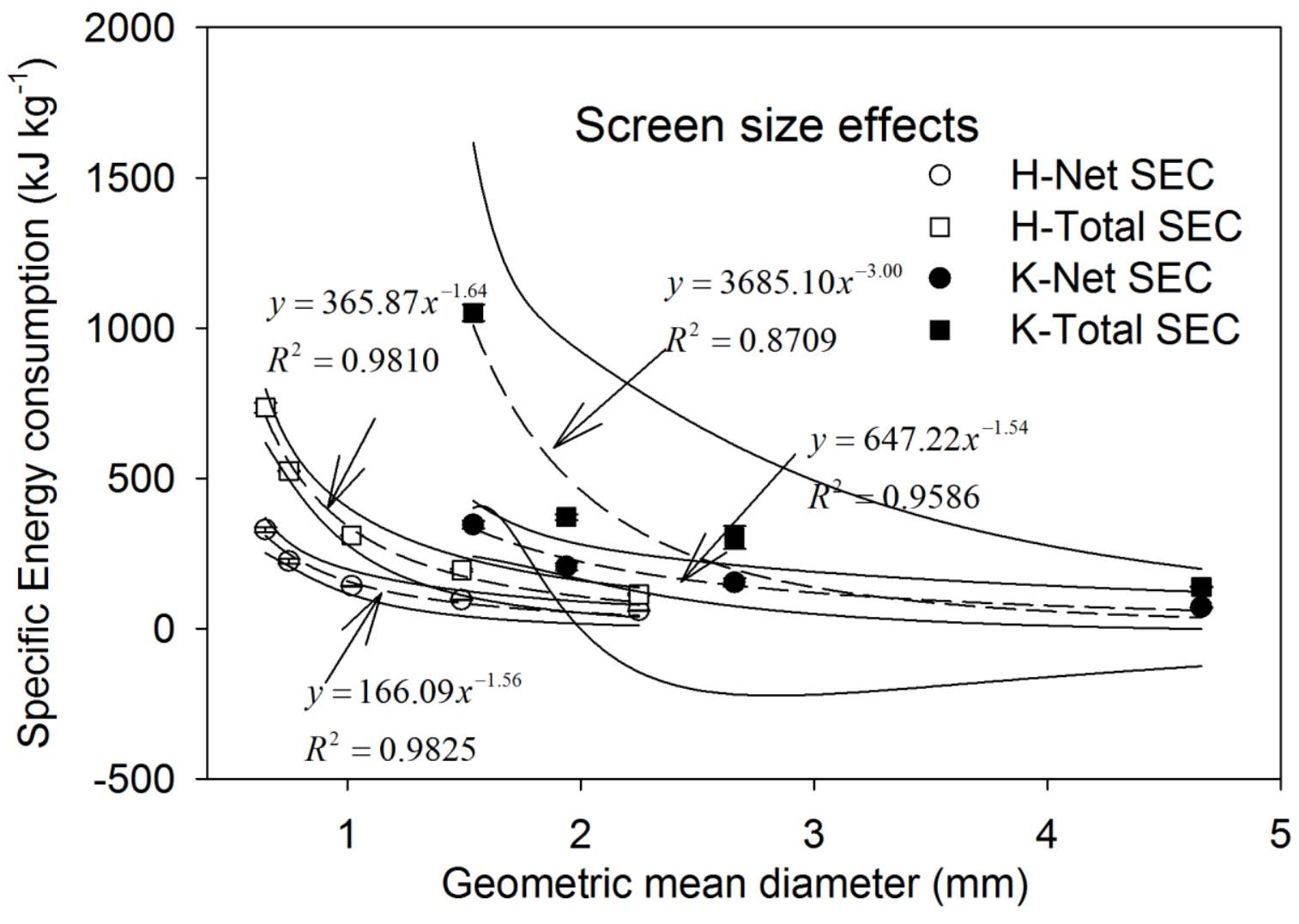




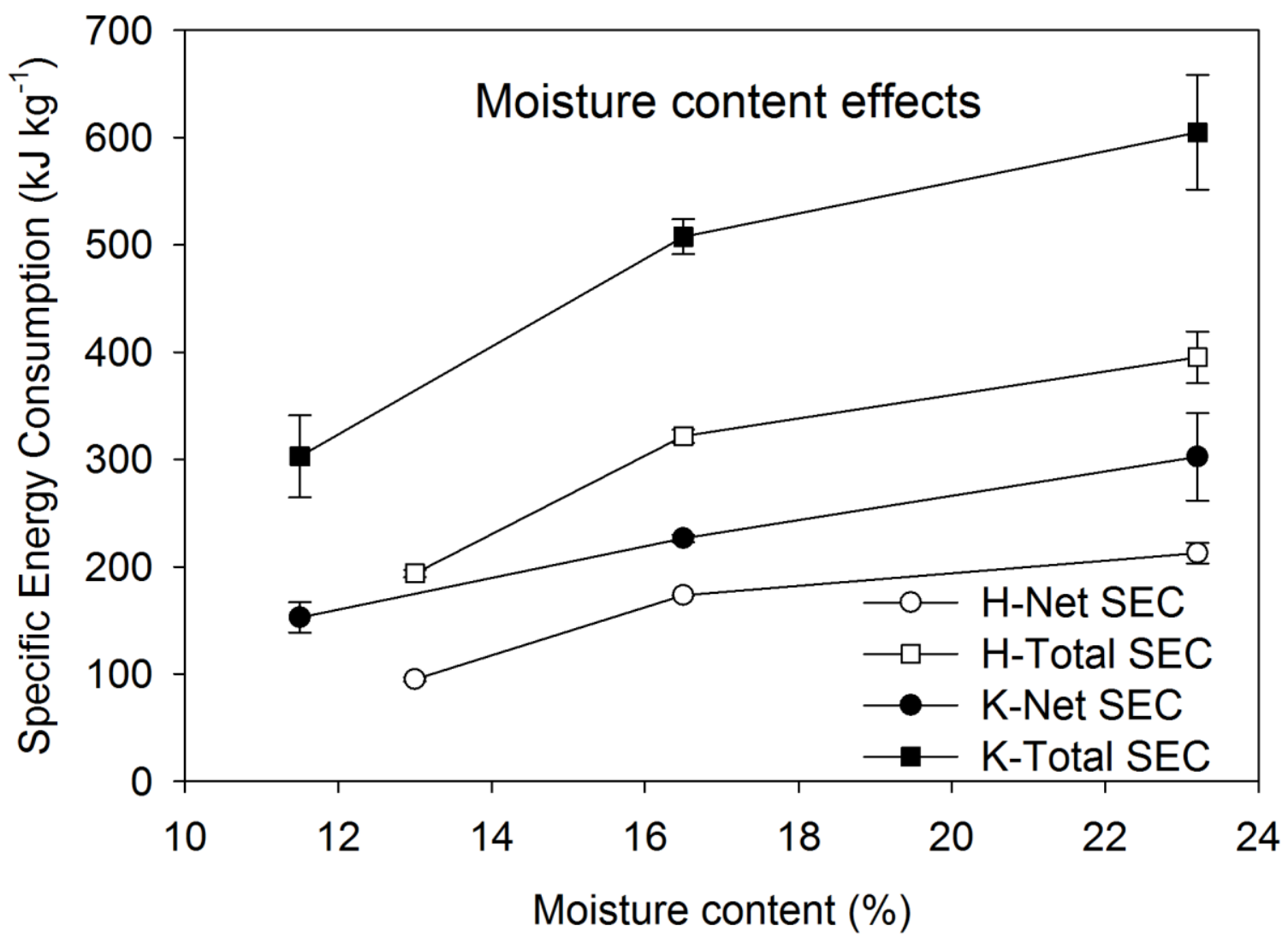




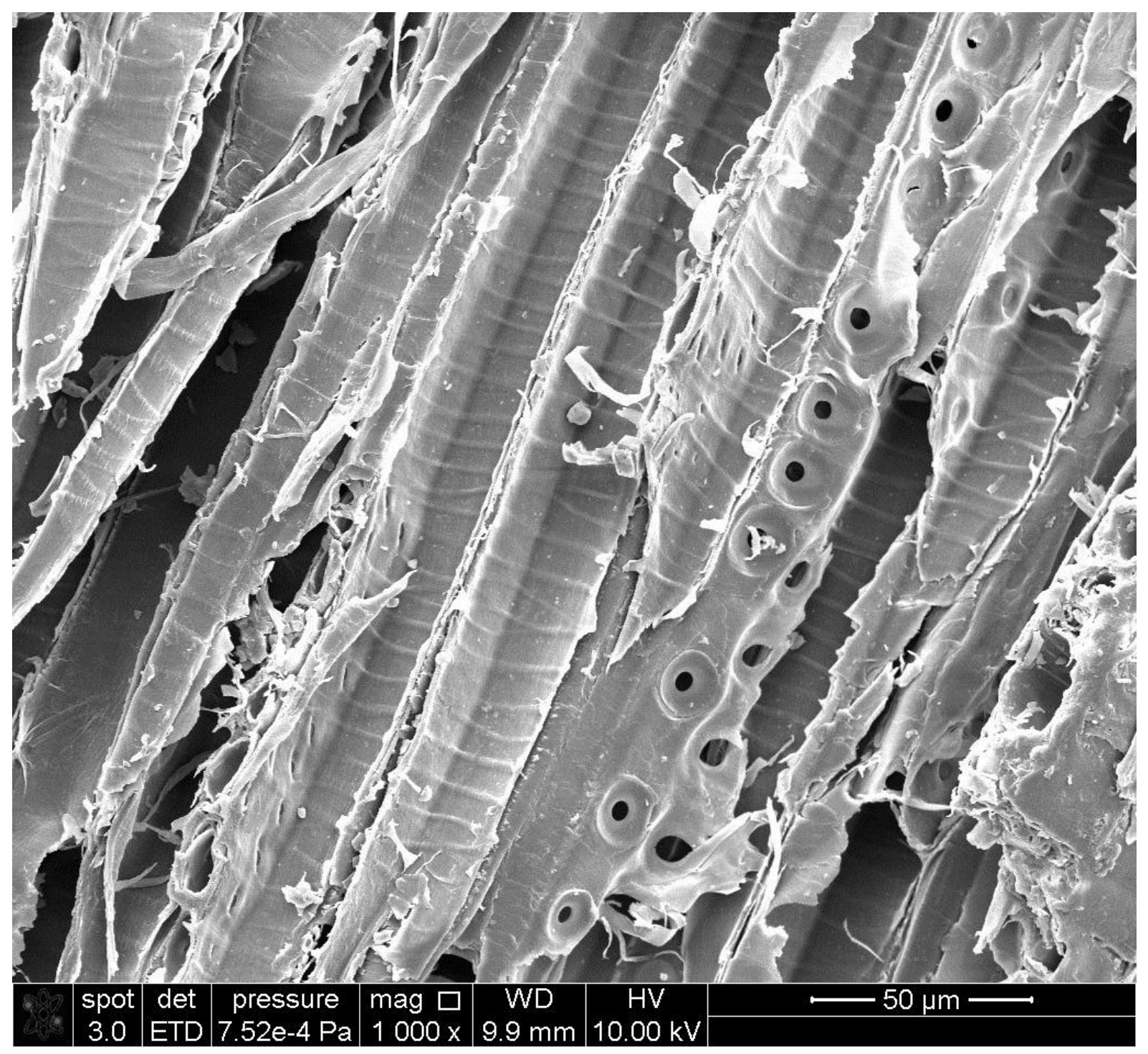









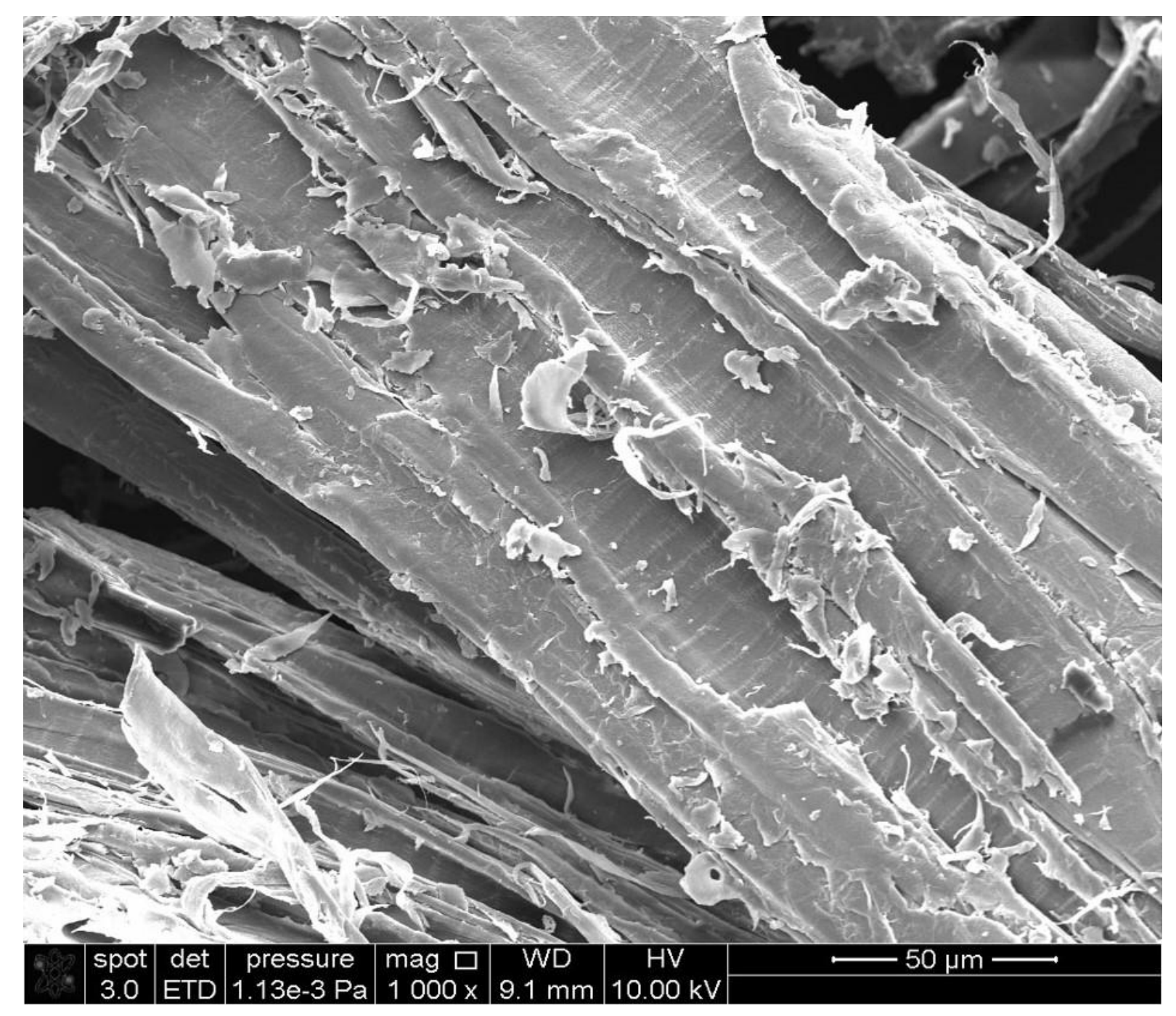




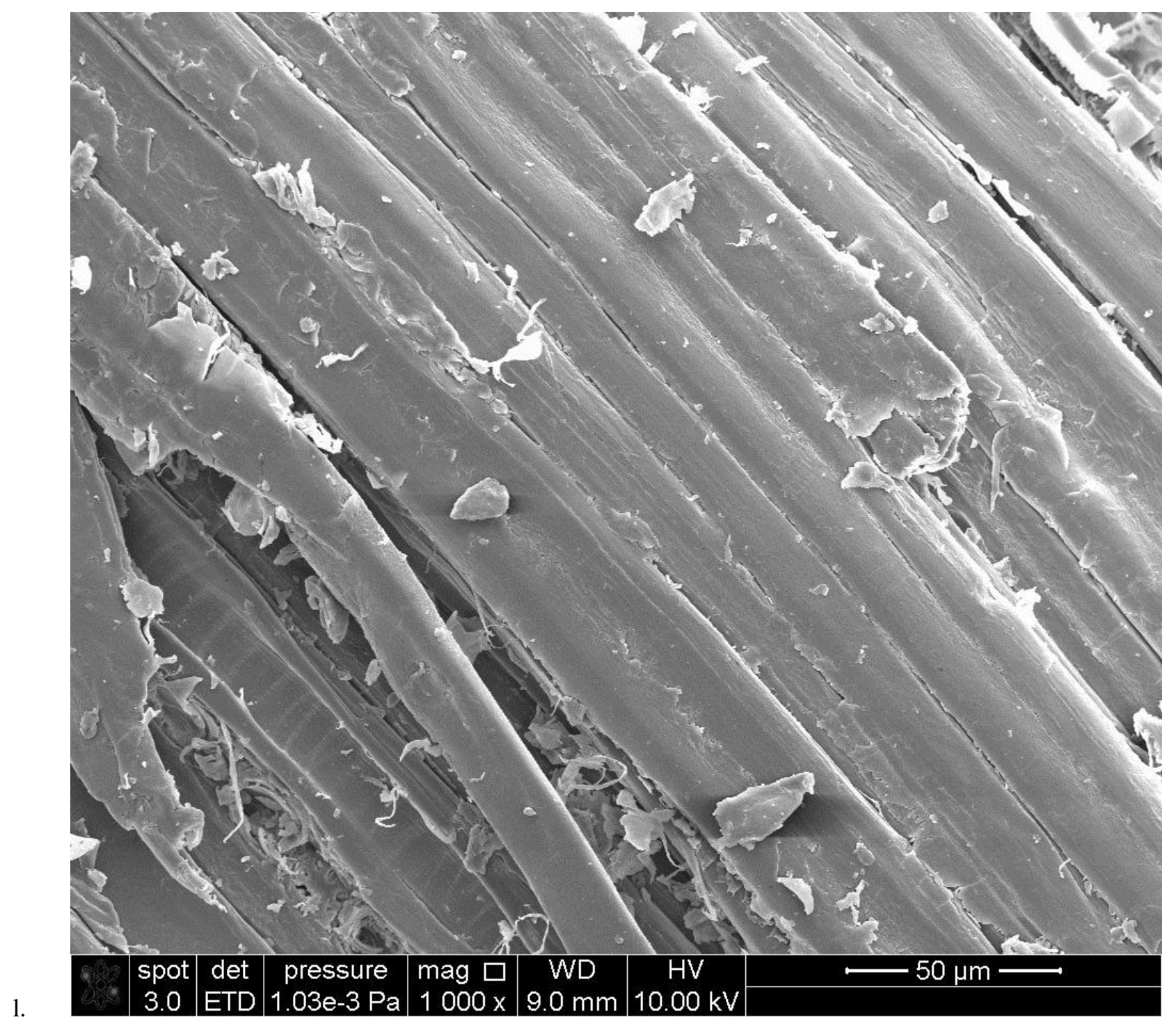




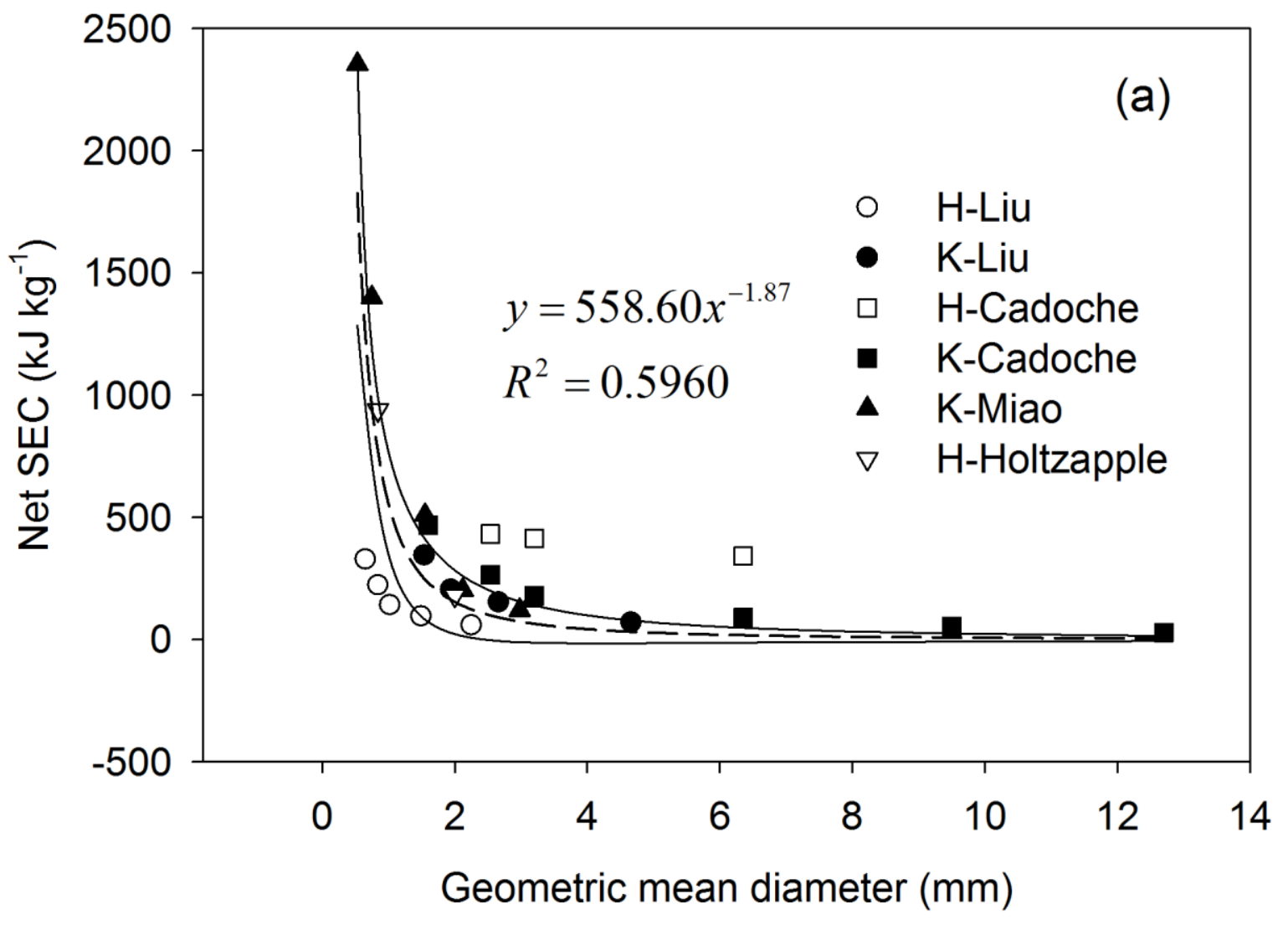




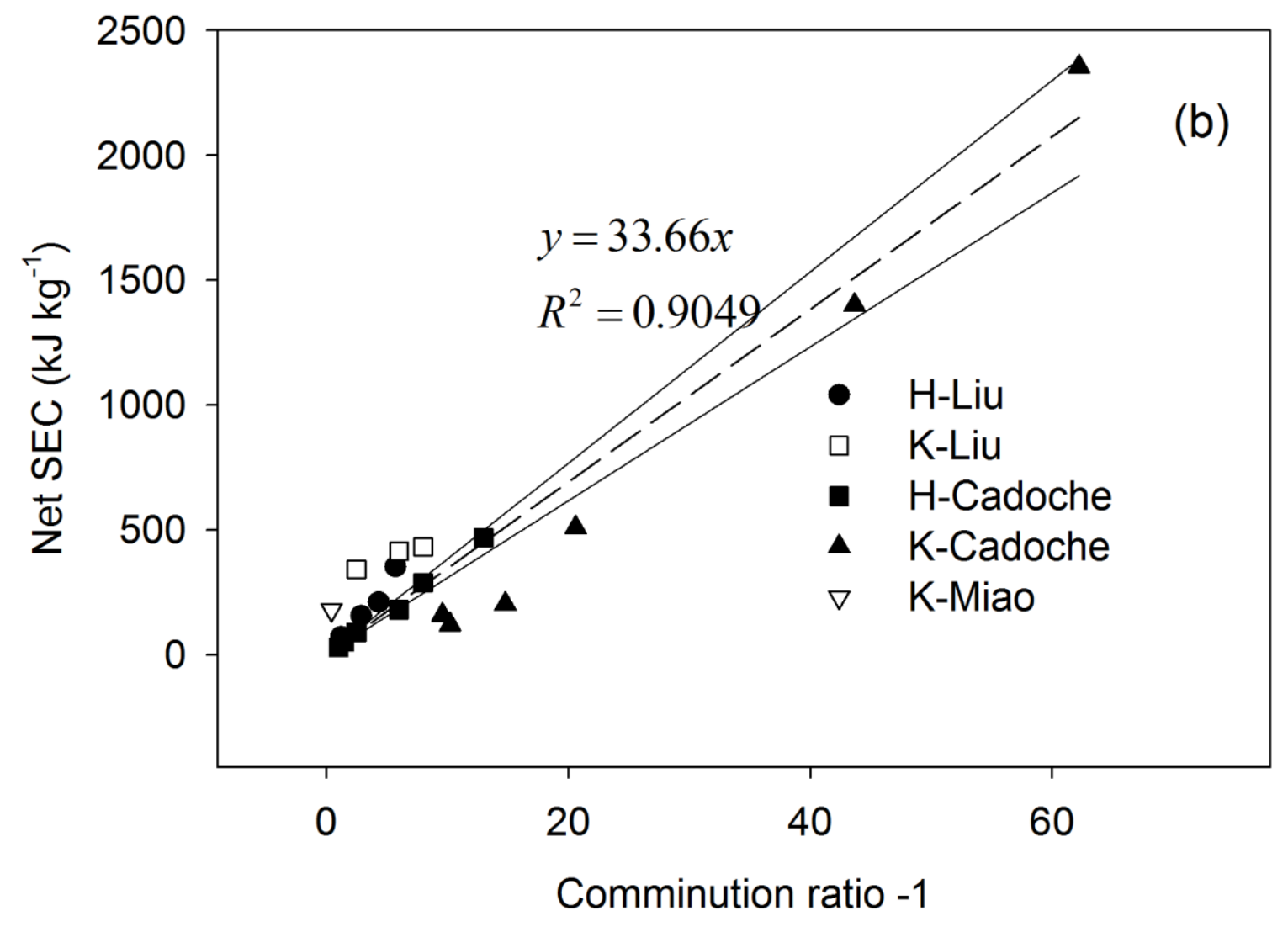

